\title{
MECHANICAL PROPERTIES OF LAMINATED STEEL-BASED COMPOSITE MATERIALS FABRICATED BY HOT ROLLING
}

\author{
MEHANSKE LASTNOSTI SLOJEV JEKLA, OSNOVANEGA NA \\ KOMPOZITNIH MATERIALIH, IZDELANIH Z VROČIM \\ VALJANJEM
}

\author{
Tomáš Kubina, Jan Nacházel \\ COMTES FHT a.s., Průmyslová 995, 33441 Dobřany, Czech Republic \\ jan.nachazel@comtesfht.cz \\ Prejem rokopisa - received: 2015-07-15; sprejem za objavo - accepted for publication: 2017-01-16
}

doi:10.17222/mit.2015.227

\begin{abstract}
The fabrication of laminated steel composites by hot rolling is described. Composite sandwiches were made from martensitic stainless tool steel with an increased nitrogen content and from standard AISI 304 steel using 3 to 7 layers. The maximum strength of the martensitic steel was $1370 \mathrm{MPa}$. The composite sheets had strengths in the range 950-1200 MPa, depending on the number of layers and the proportion of the steels. A metallographic observation of the fractures revealed that the first occurrence was fracture in the martensitic steel layers, followed by deformation of the layers of tough austenitic AISI 304 steel. The notch toughness values were the highest when the notch was oriented from the sheet surface to the sheet interior.

Keywords: laminated composite, steel sandwich, tension test, hot rolling, notch toughness

V delu je opisana izdelava laminiranih jeklenih kompozitov z vročim valjanjem. Kompozitni sestavi so bili narejeni iz martenzitnega nerjavečega orodnega jekla s povečano vsebnostjo dušika, in v skladu s standardom AISI 304 je bilo uporabljeno jeklo s 3 do 7 sloji. Maksimalna moč martenzitnega jekla je bila 1370 MPa. Moč kompozitnih slojev je bila med 950-1200 MPa, odvisno od števila slojev in proporcev jekla. Metalografska analiza zlomov je pokazala, da je najprej prišlo do zloma pri slojih martenzitnega jekla, sledila je deformacija slojev težkega avstenitnega jekla AISI 304. Vrednosti žilavosti v zarezah so bile najvišje, kjer je bila zareza usmerjena iz površine sloja v njegovo notranjost.

Ključne besede: laminirani kompozit, sestav jekla, napetostni preizkus, vroče valjanje, žilavost zareze
\end{abstract}

\section{INTRODUCTION}

Various fabrication methods can be used for making composite materials. For multi-layered laminated composites, pressure-based joining comes into consideration. In the review article by H. J. McQueen, ${ }^{1}$ the differences between pressure-based joining, diffusion bonding and friction joining are explained. In terms of production efficiency, rolling is an advantageous method, which permits the pressure-based joining of two or more dissimilar materials.

Various combinations of dissimilar roll-bonded metallic materials have been described in the literature. These included, for instance, titanium alloy/steel, ${ }^{2-3}$ aluminum alloy/aluminum alloy, ${ }^{4}$ aluminum alloy/steel, ${ }^{5}$ brass $/$ steel,${ }^{6}$ steel/steel $^{7-9}$ and other possible combinations. ${ }^{10}$

Laminated metallic composites offer an abundance of topics for study, ranging from fabrication, where the flow of layers during deformation can be explored, ${ }^{11-13}$ through their overall mechanical properties ${ }^{14}$ measured, for instance, by conventional tension testing ${ }^{10,15}$ or by three-point bend test; ${ }^{16,17}$ used for mapping delamination during failure. ${ }^{18}$ One can also investigate internal stresses on the interlayer interface, for instance, in a composite fabricated of martensitic and austenitic steels. ${ }^{19}$ It is these two steel types, austenitic and martensitic steel, that receive attention in the present paper. The focus of the paper is conventional. It covers the fabrication of laminated composite sheets and a description of their fundamental properties.

\section{EXPERIMENTAL PART}

Two stainless steels with different properties upon heat treatment were chosen for the experiments. The first, soft constituent was AISI 304L austenitic steel. It is characterized by its relatively high ductility and by an average level of tensile strength. Martensitic stainless steels have an inverted combination of properties: high strength and very low elongation upon heat treatment.

The attention was focused on a carbon steel (mark as $55 \mathrm{C} 15 \mathrm{~N}$ ) with a high nitrogen level. It was made for this particular purpose by melting in an electrical induction furnace using $\mathrm{N}_{2}$ overpressure in the final melting stage. A round ingot was cast and rolled into a 7-mm-thick sheet. The chemical composition of the $55 \mathrm{C} 15 \mathrm{~N}$ steel obtained in this way is given in Table 1. It clearly shows that the $55 \mathrm{C} 15 \mathrm{~N}$ steel is a carbon tool steel, in which corrosion resistance was achieved by no other means than alloying with chromium. As opposed to normal practice, the carbon content has been reduced and a part 
of the original carbon content has been substituted with an increased nitrogen content of $0.15 \%$ of mass fraction.

Table 1: Chemical composition of the experimental steels in mass fractions $(w / \%)$

\begin{tabular}{|c|c|c|c|c|c|c|c|c|c|c|}
\hline Steel & $\mathrm{C}$ & $\mathrm{Co}$ & $\mathrm{Cr}$ & $\mathrm{Mn}$ & $\mathrm{Mo}$ & $\mathrm{Si}$ & $\mathrm{S}$ & $\mathrm{P}$ & $\mathrm{Ni}$ & $\mathrm{N}$ \\
\hline AISI 304 & 0.08 & - & 18.20 & 2 & - & 0.75 & 0.03 & 0.045 & 8.6 & \\
\hline 55C15N & 0.52 & 0.007 & 13.628 & 0.56 & 0.03 & 0.185 & 0.003 & 0.007 & 0.07 & 0.15 \\
\hline
\end{tabular}

The surface of the sheets was ground. Stacks were assembled from $55 \mathrm{C} 15 \mathrm{~N}$ steel blanks of $7 \mathrm{~mm}$ thickness and AISI 304 steel blanks of $3 \mathrm{~mm}$ thickness. The blank size was $65 \times 250 \mathrm{~mm}^{2}$. The stacks were assembled according to the schematic drawing in Figure 1.

The designation of the specimens and the numbers of layers of the individual sheets were as follows:

- $\mathrm{S} 1-55 \mathrm{C} 15 \mathrm{~N}$ steel sheet,

- $\mathrm{S} 3$ - 1 sheet of $55 \mathrm{C} 15 \mathrm{~N}$ steel, 2 sheets of AISI 304 steel,

- S5 - 2 sheets of 55C15N steel, 3 sheets of AISI 304 steel,

- $\mathrm{S} 7$ - 3 sheets of $55 \mathrm{C} 15 \mathrm{~N}$ steel, 4 sheets of AISI 304 steel.

A verified method was employed to hold the stack together. It was GMAW welding along the entire circumference of the stack. The positions of the welds were such that in each case, a pair of sheets of different steels, i.e., $55 \mathrm{C} 15 \mathrm{~N}$ steel and AISI 304 steel, were joined by the weld.

The first pass in the rolling process involved a thickness reduction denoted as $\varepsilon_{\mathrm{h}}$. It was approximately equal to $23 \%$ engineering strain, as calculated from the actual stack height $h$. Additional passes involved thickness reductions of $27 \%$. All the specimens were rolled to a thickness of $4.1 \mathrm{~mm}$. The soaking temperature and time were $1100{ }^{\circ} \mathrm{C}$ and $40-60 \mathrm{~min}$, respectively. The rolling operations were carried out in the laboratory rolling mill at COMTES FHT a.s. The work rolls had a diameter of $550 \mathrm{~mm}$. Upon rolling, the scale was removed by grinding to achieve the final thickness of $4 \mathrm{~mm}$.

The S7 specimen was reheated upon the fifth pass using the soaking parameters: $1100{ }^{\circ} \mathrm{C}$ and $40 \mathrm{~min}$. The rolled specimens were cooled in still air.

Given the limited width of the laminated rolled sheet, the orientation of the specimens for tension testing was chosen in the rolling direction. ${ }^{21}$ The test pieces for impact testing with the dimensions of $(4 \times 4 \times 25) \mathrm{mm}^{3}$ were

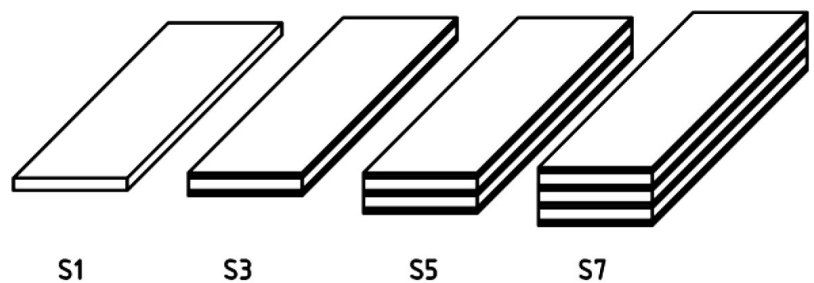

Figure 1: Configuration of sheets in stacks. Each white layer represents a 7 -mm-thick sheet of $55 \mathrm{C} 15 \mathrm{~N}$ steel, each black layer represents a sheet of AISI 304 steel of $3 \mathrm{~mm}$ thickness

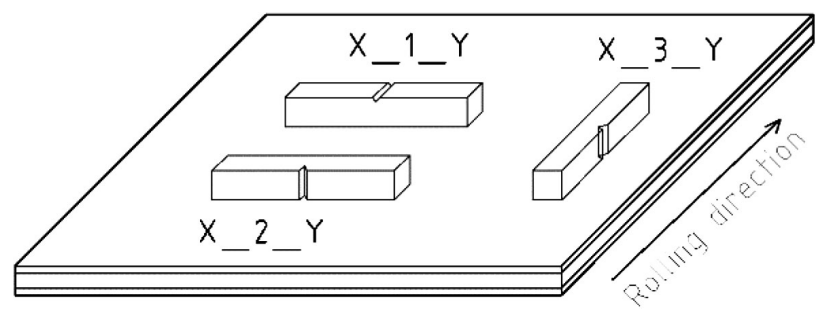

Figure 2: Schematic representation of samples taken from rolled sheets for Charpy impact test; $\mathrm{X}$ stands for the stack number and $\mathrm{Y}$ denotes the sequential number of the test piece

machined according to the sketch in Figure 2, which shows the orientation of the 1-mm-deep V notches.

The procedure for finding the appropriate heat-treating sequence is described in ${ }^{21}$. Considering the expected use of the $55 \mathrm{C} 15 \mathrm{~N}$ steel, the final hardness of this steel in the sandwich products was specified as 57 HRC. All the mechanical testing specimens were pre-treated as follows:

- sheets were painted with a protective coating,

- heating to $1050{ }^{\circ} \mathrm{C}$ and holding for $30 \mathrm{~min}$,

- oil quenching,

- tempering at $175^{\circ} \mathrm{C}$ for $2 \mathrm{~h}$.

The specimens were then prepared using a standard metallographic procedure involving grinding and subsequent polishing.

The macro and microstructure in the ingots and rolled sheets of $55 \mathrm{C} 15 \mathrm{~N}$ steel were revealed by etching with nital, i.e., a $5 \%$ solution of nitric acid.

The microstructure in the tension test pieces was revealed by etching with Marble's reagent (bringing out one constituent) and then with Beraha 2 (bringing out the other constituent). The un-etched microstructure and the microstructures upon consecutive etching steps were documented using a Carl Zeiss - Observer.Z1m optical microscope. The microscope workstation is equipped with AxioVision Rel. 4.8 digital image-processing software.

The fracture surfaces in tension and the impact test pieces were documented using a JEOL JSM 6380 scanning electron microscope (SEM), which is provided with an Oxford INCA X-sight EDX detector for measuring the local chemical composition.

\section{RESULTS AND DISCUSSION}

\subsection{Sandwich fabrication by rolling}

In the course of the sandwich rolling process, rolling forces, torque values, surface temperatures measured by pyrometers and the set rolled product thickness were recorded. An example of mean values measured and calculated for S3 specimen is given in Table 2. The first-pass rolling force $F$ for all three stacks was around $630 \mathrm{MPa}$. Due to different initial heights, the torque values $(M)$ were in the range from $20 \mathrm{kNm}$ to $45 \mathrm{kNm}$. The strain rate $(\dot{\mathrm{e}})$ in the first pass was $2.3-3.6 \mathrm{~s}^{-1}$. 


\section{T. KUBINA, J. NACHÁZEL: MECHANICAL PROPERTIES OF LAMINATED STEEL-BASED COMPOSITE MATERIALS ...}

Table 2: Measured and calculated mean values of fundamental rolling parameters for $\mathrm{S} 3$ specimen

\begin{tabular}{|c|c|c|c|c|c|c|}
\hline \multirow{2}{*}{ pass } & $h$ & $\varepsilon_{h}$ & $v_{v}$ & $F$ & $M$ & $\dot{e}$ \\
\cline { 2 - 7 } & $\mathrm{mm}$ & - & $\mathrm{ms}^{-1}$ & $\mathrm{kN}$ & $\mathrm{kNm}$ & $\mathrm{s}^{-1}$ \\
\hline 0 & 14 & & & & & \\
\hline 1 & 10.7 & 0.238 & 0.5 & 629 & 20.6 & 3.6 \\
\hline 2 & 7.8 & 0.267 & 0.9 & 857 & 19.8 & 8.2 \\
\hline 3 & 5.7 & 0.267 & 0.9 & 1283 & 29.8 & 9.6 \\
\hline 4 & 4.2 & 0.267 & 0.9 & 1519 & 28.2 & 11.0 \\
\hline
\end{tabular}

Considering the initial sandwich width of $65 \mathrm{~mm}$, the rolling-force values are not high. They are normally below $2000 \mathrm{kN}$, despite the fact that the reductions $\varepsilon_{\mathrm{h}}$ in individual passes exceeded $25 \%$. The calculated strain rates (è) were between 2 and $11 \mathrm{~s}^{-1}$. The rolling speeds $\left(v_{v}\right)$ were 0.5 and $0.9 \mathrm{~m} \cdot \mathrm{s}^{-1}$.

These rolling parameters were sufficient for adequate layer bonding within all the sandwiches. A joint in the S5 specimen is documented in Figure 3. A line of iron oxides on the interface can be seen. Similar structures were found in the S3 and S7 specimens.

Table 3: Layer-thickness ratios in individual sandwiches

\begin{tabular}{|c|c|c|}
\hline \multirow{2}{*}{ specimen } & \multicolumn{2}{|c|}{ Layer thickness ratios } \\
\cline { 2 - 3 } & Initial & Post-rolling \\
\hline S3 & $1: 2.33: 1$ & $1: 2.614: 1$ \\
\hline S5 & $1: 2.33: 1: 2.33: 1$ & $1: 2.59: 0.93: 2.59: 1$ \\
\hline \multirow{2}{*}{ S7 } & $1: 2.33: 1: 2.33: 1: 2.33: 1$ & $\begin{array}{c}1: 2.56: 0.87: 2.27: 0.87: 2 . \\
56: 1\end{array}$ \\
\hline
\end{tabular}

The layer thicknesses in specimens S3, S5 and S7 are given in Table 3 . These post-rolling ratios were found by microstructure examination under an optical microscope. A detailed analysis of thickness evolution vs. rolling parameters, as reported in ${ }^{11}$, was impossible, due to multiple passes having been carried out. Despite that, it was confirmed that the "soft" constituent, AISI 304L steel, undergoes larger reductions than the $55 \mathrm{C} 15 \mathrm{~N}$ steel.

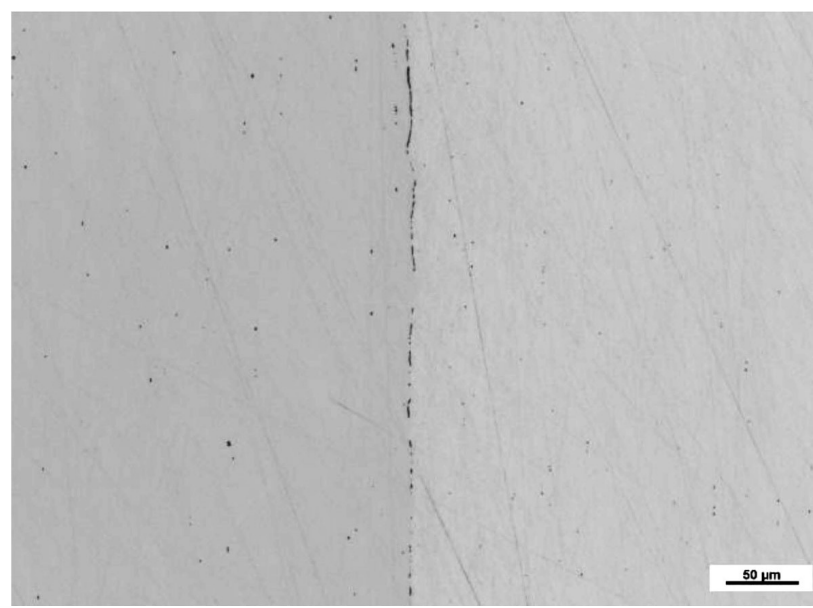

Figure 3: Joint between the $55 \mathrm{C} 15 \mathrm{~N}$ steel layer and AISI 304 steel layer; un-etched microstructure

\subsection{Mechanical properties of rolled sandwiches}

The test pieces used for the tension testing were oriented in the forming direction. Three specimens from each sandwich were tested. The test results plotted as engineering stress vs. strain curves are shown in Figure 4.

The specimen denoted as $\mathrm{S} 1$ represents the $55 \mathrm{C} 15 \mathrm{~N}$ steel upon heat treatment to a hardness of 57 HRC. The laminated composite sheets exhibit lower hardness values. Among the composites, the highest strength of $1210 \mathrm{MPa}$ was found in the 7-layer sheet. This sheet contained the largest volume fraction of $55 \mathrm{C} 15 \mathrm{~N}$ steel. The AISI 304 steel had a strength of $580 \mathrm{MPa}$ and elongation to fracture of more than $85 \%$. The pure $55 \mathrm{C} 15 \mathrm{~N}$ steel had a low ductility, which corresponds to the heat treatment procedure used. This is characteristic of tool steels. The micrographs of the fracture regions in the tension test pieces (Figure 5) show that the fractures were of the brittle type, initiating in the $55 \mathrm{C} 15 \mathrm{~N}$ steel layers. Then, the austenitic steel layers underwent large deformation and the fracture of the entire specimen occurred. This is in agreement with the behavior described in the review article by J. Wadsworth. ${ }^{22}$

Three different specimen orientations were used for taking samples for impact testing. No effect of the notch or specimen orientation was proved by the impact tough-

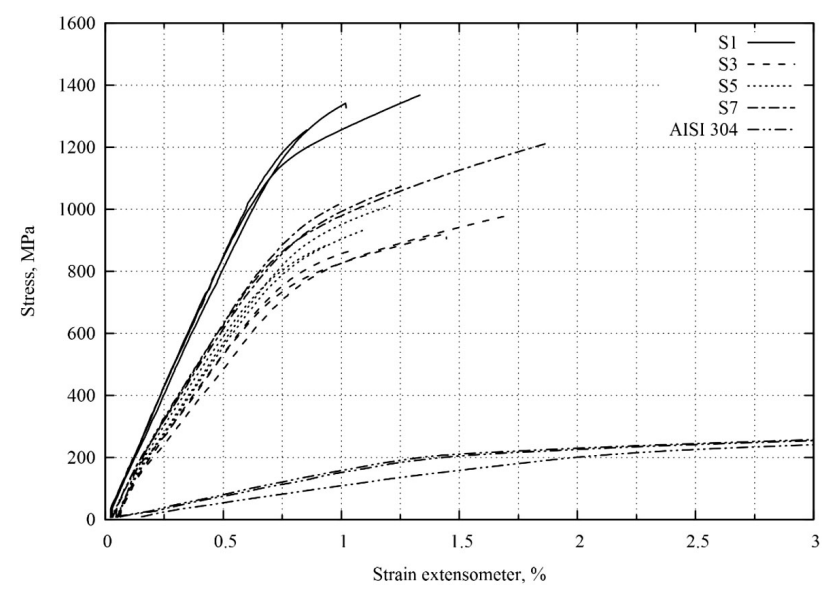

Figure 4: Engineering stress vs. strain plot of the sandwich sheet tension test

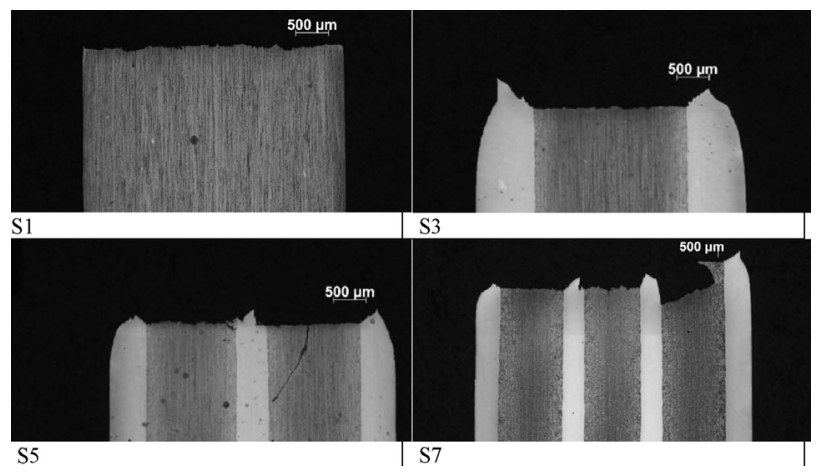

Figure 5: Micrographs of fractures in tension test pieces of sandwich sheets 
T. KUBINA, J. NACHÁZEL: MECHANICAL PROPERTIES OF LAMINATED STEEL-BASED COMPOSITE MATERIALS ...

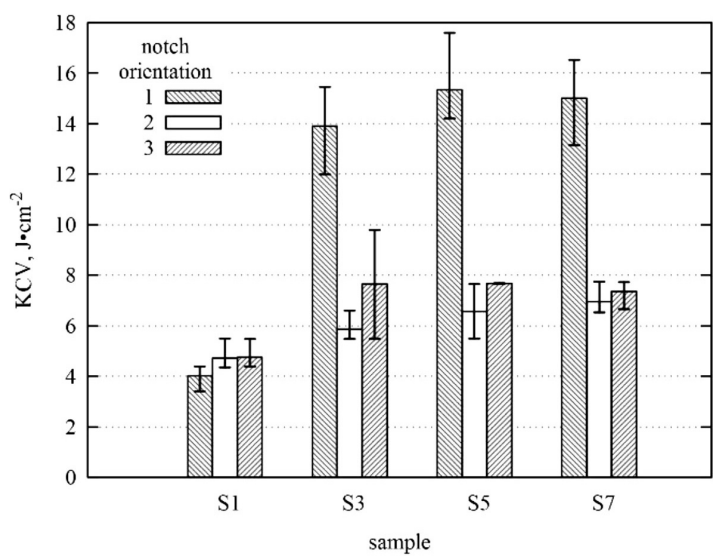

Figure 6: Impact energy KCV measured in heat-treated composite sheets

ness test of the material with a single $55 \mathrm{C} 15 \mathrm{~N}$ steel layer, as illustrated in Figure 6, specimen designation $\mathrm{S} 1$. For the specimens taken in the transverse direction with respect to the rolling direction and provided with notches in a direction oriented from the rolled sheet surface (the group denoted 1), the impact energy (13-15 $\mathrm{Jcm}^{-2}$ ) approximately doubled when compared to the previous case. There is a clear effect of the AISI 304 steel layer, which retards the crack propagation. Neither the orientation of the notch across all the layers, nor the transverse or longitudinal orientation of the specimen has any effect, as evidenced by the minimal differences between impact energy levels. In the specimens made entirely of AISI 304 steel, the impact energy was $135 \mathrm{Jcm}^{-2}$.

The fracture surfaces in the tensile and impact test specimens were examined using scanning electron microscopy. In the fracture surfaces of the tension test pieces, inclusions were found in the $55 \mathrm{C} 15 \mathrm{~N}$ steel. They were identified by means of EDX analysis as complex aluminum oxides. Examples of the measured chemical composition of the inclusions are summarized in Table 4. Figure 7 shows the fracture surface in the $55 \mathrm{C} 15 \mathrm{~N}$ steel layer in the seven-layer sandwich. In all cases, the

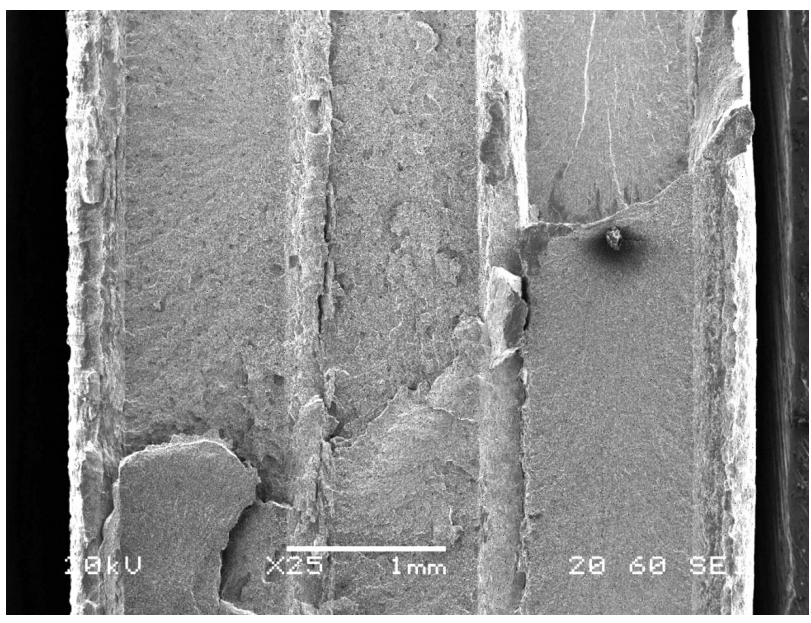

Figure 7: Fracture surface of S7 test piece fracture surfaces examined showed transgranular fracture morphology. In the fracture surfaces of the impact test pieces, no aluminum oxides were found.

Table 4: Chemical composition of inclusions in mass fractions ( $w / \%)$, measured by EDX

\begin{tabular}{|c|c|c|c|c|c|c|}
\hline Elements & $\mathrm{O}$ & $\mathrm{Al}$ & $\mathrm{Si}$ & $\mathrm{Cr}$ & $\mathrm{Mn}$ & $\mathrm{Fe}+\mathrm{C}$ \\
\hline Inclusion 1 & 53.24 & 32.57 & 1.28 & 5.22 & - & balance \\
\hline Inclusion 2 & 42.77 & 40.82 & - & 3.64 & - & balance \\
\hline Inclusion 3 & 35.11 & 37.80 & 5.01 & 14.76 & 4.75 & balance \\
\hline
\end{tabular}

\section{CONCLUSIONS}

A fabrication procedure for laminated composite materials was mastered, in which two different steels were joined by hot rolling. The resulting sandwiches containing martensitic stainless tool steel and austenitic steel were rolled to a thickness of $4 \mathrm{~mm}$ and heat-treated to a hardness of $57 \mathrm{HRC}$ in the $55 \mathrm{C} 15 \mathrm{~N}$ steel layers. Oxides were found at the interface between the martensitic $55 \mathrm{C} 15 \mathrm{~N}$ and austenitic AISI 304 steels. They, however, had no impact on the delamination between the layers during the mechanical testing.

No contribution of austenitic AISI 304 steel to ductility enhancement was proved. It can be attributed to the small number of its layers. The impact energy value measured with impact tests suggests an increased resistance in cases where the notch is oriented from the sheet surface to its centerline, where the presence of the tough austenitic steel layers is beneficial.

\section{Acknowledgements}

The present paper was developed under the Development of the West Bohemian Centre of Materials and Metallurgy project, reg. No. LO1412, which was funded by the Ministry of Education of the Czech Republic.

\section{REFERENCES}

${ }^{1}$ H. J. McQueen, Pressure welding, solid state: role of hot deformation, Canadian Metallurgical Quarterly, 51 (2012) 3, 239-249, doi:10.1179/1879139512Y.0000000011

${ }^{2}$ K. Lee, D. Yoon, S. Lee, Y. Lee, The effect of thermomechanical treatment on the interface microstructure and local mechanical properties of roll bonded pure Ti/439 stainless steel multilayered materials, Procedia Engineering, 10 (2011), 3459-3464, doi:10.1016/j.proeng.2011.04.570

${ }^{3}$ J. C. Yan et al., Vacuum hot roll bonding of titanium alloy and stainless steel using nickel interlayer, Materials Science and Technology, 25 (2009) 7, 914-918, doi:10.1179/174328408X365766

${ }^{4}$ C. M. Cepeda-Jimenez et al., Influence of constituent materials on the impact toughness and fracture mechanisms of hot-roll-bonded aluminum multilayer laminates, Metallurgical and Materials Transactions A, 41A (2010) 1, 61-72, doi:10.1007/s11661009-0069-x

${ }^{5}$ J. W. Yuan, Y. H. Pang, T. Li, Multilayer clad plate of stainless steel/aluminum/aluminum alloy, Journal of Wuhan University of Technology materials Science Edition, 26 (2011) 1, 111-113, doi:10.1007/s11595-011-0179-3 


\section{MATERIALI IN TEHNOLOGIJE/MATERIALS AND TECHNOLOGY (1967-2017) - 50 LET/50 YEARS}

\section{T. KUBINA, J. NACHÁZEL: MECHANICAL PROPERTIES OF LAMINATED STEEL-BASED COMPOSITE MATERIALS ...}

${ }^{6}$ H.-Y. Wu, S. Lee, J.-Y. Wang, Solid-state bonding of iron-based alloys, steel-brass, and aluminum alloys, Journal of Materials Processing Technology, 75 (1998) 1-3, 173-179, doi:10.1016/ S0924-0136(97)00323-3

${ }^{7}$ F. X. Yin et al., Hot rolling bonded multilayered composite steels and varied tensile deformation behaviour, Materials Science and Technology, 28 (2012) 7, 783-787, doi:10.1179/1743284711Y. 0000000116

${ }^{8}$ S. Nambu, M. Michiuchi, J. Inoue, T. Koseki, Effect of interfacial bonding strength on tensile ductility of multilayered steel composites, Composites Science and Technology, 69 (2009) 11-12, 1936-1941, doi:10.1016/j.compscitech.2009.04.013

${ }^{9}$ Q. X. Huang et al., Interface-correlated characteristics of stainless steel/carbon steel plate fabricated by AAWIV and hot rolling, Journal of Iron and Steel Research International, 21 (2014) 10, 931-937, doi:10.1016/S1006-706X(14)60164-3

${ }^{10}$ A. Cohades, A. Cetin, A. Mortensen, Designing laminated metal composites for tensile duktility, Materials \& Design, 66 (2015) 412-420, doi:10.1016/j.matdes.2014.08.061

${ }^{11}$ G. P. Chaudhari, V. Acoff, Cold roll bonding of multi-layered bi-metal laminate composites, Composites Science and Technology, 69 (2009) 10, 1667-1675, doi:10.1016/j.compscitech.2009.03.018.

${ }^{12}$ Y.-M. Hwang, H.-H. Hsu, H.-J. Lee, Analysis of plastic instability during sandwich sheet rolling, International Journal of Machine Tools and Manufacture, 36 (1996) 1, 47-62, doi:10.1016/08906955(95)92628-C

${ }^{13}$ X. P. Zhang et al., Proposal of bond criterion for hot roll bonding and its application, Materials \&Design, 32 (2011) 4, 2239-2245, doi:10.1016/j.matdes.2010.11.039

${ }^{14}$ D. R. Lesuer et al., Mechanical behaviour of laminated metal composites, International Materials Reviews, 41 (1996) 5, 169-197, doi:10.1179/imr.1996.41.5.169
${ }^{15}$ A. Cetin, C. Bernardi, A. Mortensen, An analysis of the tensile elongation to failure of laminated metal composites in the presence of strain-rate hardening, Acta Materialia, 60 (2012) 5, 2265-2276, doi:10.1016/j.actamat.2011.12.041

${ }^{16} \mathrm{~J}$. Yanagimoto et al., Enhancement of bending formability of brittle sheet metal in multilayer metallic sheets, CIRP Annals - Manufacturing Technology, 59 (2010) 1, 287-290, doi:10.1016/j.cirp. 2010.03.109

${ }^{17}$ E. Corona, T. Eisenhour, Wiping die bending of laminated steel, International Journal of Mechanical Sciences , 49 (2007) 3, 392-403, doi:10.1016/j.ijmecsci.2006.08.007

${ }^{18}$ M. Pozuelo, F. Carreno, O. A. Ruano, Delamination effect on the impact toughness of an ultrahigh carbon-mild steel laminate composite, Composites Science and Technology, 66 (2006) 15, 2671-2676, doi:10.1016/j.compscitech.2006.03.018

${ }^{19}$ R. I. Barabash et al., Interphase strain gradients in multilayered steel composite from microdi-ffraction, Metallurgical and Materials Transactions A, 45A (2014) 1, 98-108, doi:10.1007/s11661-0132100-5

${ }^{20}$ ČSN EN ISO 6892-1 (420310). Metallic materials - Tensile testing Part 1: Method of test at room temperature

${ }^{21} \breve{S}$. Tománek, Preparation of composite plates from different tool steels and their mechanical properties (in czech), Diploma thesis. VŠB-Technical Univerzity of Ostrava, Faculty of Metallurgy and Materials Engineering, Department of Materials Forming, Ostrava (2015)

22 J. Wadsworth, Ancient and modern steels and laminated composites containing steels, MRS Bulletin, 27 (2002) 12, 980-987, doi: $10.1557 / \mathrm{mrs} 2002.305$ 